\title{
Sığır, Koyun ve Keçilerin Bovine Parainfluenza 3 Virus Enfeksiyonuna Duyarlılıklarının Saha Şartlarında Serolojik Olarak Karşılaştırılması
}

\author{
Sibel Gür \\ Afyon Kocatepe Üniversitesi, Veteriner Fakültesi, Viroloji Anabilim Dall, Afyonkarahisar.
}

Geliş Tarihi / Received: 09.02.2019, Kabul Tarihi / Accepted: 29.03.2019

\begin{abstract}
Özet: Sığır Parainfluenza tip 3 virusu (BPI3V), tüm ruminantlarda özellikle sığırlarda solunum bozukluklarına neden olan en önemli etkenler arasındadır. Koyun, keçi ve sığılların bu enfeksiyona duyarlılık seviyelerini karşılaştırmak için aynı çiftlik koşullarında en az bir yıl veya daha fazla bir süredir birlikte yetiştirilen hayvanlardan kan örnekleri alındı. Örnekler Kütahya, Manisa ve Afyonkarahisar illerindeki 12 küçük-orta ölçekli özel çiftliklerden elde edildi. 117 sığır, 432 koyun ve 302 keçinin serumları BPI3V için Serum Nötralizasyon Testi ile incelendi. Test sonuçlarına göre, seropozitiflik sığır, koyun ve keçilerde sırasıyla\%76.9, \%21.9 ve \%27.8 olarak belirlendi. Antikor titrelerinin geometrik ortalaması sığırlarda 1:28, koyunlarda 1:10.9 ve keçilerde 1:10 idi. Enfeksiyona maruz kalmanın tüm türlerde, özellikle de sığırlarda yaygın olduğu bulundu. Koyun ve keçilerin duyarlılı̆̆ neredeyse aynıydı ancak sığırlardan daha azdı. Sonuç olarak, koyun ve keçilerin sığıllar için rezervuar konakçı olamayacağı, ancak sığırların bu diğer iki tür için daha yüksek risk potansiyeline sahip olabileceği belirlendi.
\end{abstract}

Anahtar kelimeler: BovineParainfluenza 3 Virus, Koyun, Keçi, Sığır.

\section{Serological Comparison of Sensitivity of Cattle, Sheep and Goats to Bovine Parainfluenza 3 Virus Infection in Field Conditions}

\begin{abstract}
Bovine Parainfluenzatype 3 virus (BPI3V) are among the prominent agent that cause respiratory disorders in all ruminant species especially in cattle. In order to determine the susceptibility levels of sheep, goats and cattle to this infection, blood samples were obtained from animals that have been breeding together at the same farm conditions for at least one year or more. Samples were obtained from 12 small-medium scale private farms in Kütahya, Manisa and Afyonkarahisar provinces. The sera of 117 cattle, 432 sheep and 302 goats were examined by Serum Neutralization Test for BPI3V. According to test results, seropositivity was determined as $76.9 \%, 21.9 \%$ and $27.8 \%$, in cattle, sheep and goats, respectively. The geometric mean of antibody titres was 1: 28 in cattle, 1: 10.9 in sheep and 1:10 in goats. Exposure to the infection was common in all species, especially in cattle. The sensitivity of sheep and goats was almost the same and less than that of cattle. As a result, sheep and goats could not be reservoir hosts for cattle, but cattle could have higher risk potential for other two species.
\end{abstract}

Key words: BovineParainfluenza 3 Virus, Serology, Turkey

\section{Giriş}

Evcil ruminant yetiştiriciliğinde tüm dünyada, özellikle gelişmiş ülkelerde en önemli sağlık sorunlarından biri solunum sistemi bozukluklarıdır [9]. Et ve süt veriminde azalma, ilaç ve tedavi giderleri ile işçilik maliyetindeki artışlar nedeniyle ciddi ekonomik kayıplara yol açar [33]. Akut solunum sistemi bozukluklarının (SSB) ortaya çıkmasında etkili olan birçok faktörün başında son derece çeşitli olabilen etiyolojik ajanlar gelir. Bakteri ve viruslar birlikte veya ayrı olarak etkin olabilir iseler de [4], asıl ajan genellikle viruslardır [8]. Solunum sistemi enfeksiyonlarının gelişimine neden olabilen çok sayıda viral etken bulunmakla birlikte, sahada en sik izole edilen viruslar Bovine Parainfluenza tip 3 virus (BPI3V), Bovine Herpesvirus tip 1 (BoHV1), Bovine Respiratory Syncytial Virus (BRSV), Bovine Viral Diarrhea Viruslarıdır (BVDV) ve bu virusların sıklıkla miks seyrettiği bildirilmektedir $[8,10,12,17,19,28,29,31]$. Ülkemizde de solunum sistemi viruslarının varlık ve yaygınlıklarına yönelik çok sayıda araştırma bulunmaktadır $[2,6$, $11,30,34]$.

BPI3V, Paramyxoviridae familyasının Paramyxovirinae alt familyası içerisinde bulunan Respirovirus genusuna dahil, zarl1, negatif polariteli, tek iplikcikli RNAvirusu olup, monopartit genom ile helikal simetrili nükleokapside sahip bir virustur 
$[18,28]$. Referens suşu Shipping Fever 4'tür (SF4). Saha izolatlarının filogenetik analizi sonucunda virus a, b ve c olarak üç genotip altında sınıflandırılmış, bunların da alt tipleri olduğu bildirilmiştir [23, $25,27]$. Başlica solunum sistemini etkileyen virus, saha şartlarında son derece yaygın olarak bulunması nedeniyle, dengesiz beslenme, kapalı intensif yetiştirme, hayvanların taşınmaları gibi immundepresyona yol açan şartların varlığında akut olarak görülür ve diğer bakteriyel ve viral etkenlerin gelişimine predispozisyon oluşturarak enzootik bronko-pneumonilerin şekillenmesine yol açar [10, 12, 16, 19].

Deneysel enfeksiyonlarda sığır, koyun ve keçilerde benzer bozuklukların şekillendiği görülmüştür. Bryson ve ark. [5] kolostrum verilmemiş 13 danada yaptıkları deneysel çalışmada tipik semptomların 12 danada geliştiğini bildirmişler, patolojik incelemede ise, tüm solunum sisteminde antijen varlığ 1 , üst ve alt solunum sisteminde epitel hücrelerinde ve alveolar makrafajlarda hiperplazi ve nekroz, siliyal hücrelerde silyum kayıpları ile tip 2 pnömonositlerde hiperplazi sonucu interalveoler septalarda kalınlaşmalar olduğunu tespit etmişlerdir. Keçilerde yapılan deneysel bir çalışmada [1], 11 keçi enfekte edilmiş, viral saçılımın 6. güne kadar devam etmesine rağmen semptom görülmediği ve BPI3V spesifik antikorların en erken 12. günde ortaya çıktığ arasında ötenazi yapılarak alınan örneklerde trake, tonsil, retrofaringeal ve bronşial lenf nodülleri ve akciğer dokularında 2-5. günler arasında virus varl1ğ1 saptanmıştır. Lehmkul ve Cutlip [22], bir haftalık kolostrum almamış 5 kuzuya virus inokule etmişler, bifazik ateş, öksürük ve solunum güçlüğü, anoreksi, akciğerlerde multifokal konsolidasyon alanları, nazal mukozada ülserasyonlar belirlemiş, antijen varlığı nazal sekresyonlarda, trakeal sıvıda ve akciğer dokusunda tespit edilmiş ve tüm kuzuların serokonversiyon gösterdiklerini bildirmişlerdir.

Koyun ve keçilerin BPI3V enfeksiyonuna duyarlı oldukları hem deneysel enfeksiyonlar [1, 22], hem de saha çalışmaları $[3,14,20,26,32,37,38]$ ile gösterilmiş ise de, tür duyarlılıkları açısından dikkate değer bir farklılık olup olmadığı bilinmemektedir. $\mathrm{Bu}$ çalışmada aynı işletmede, aynı koşullar altında birlikte yetiştirilen sığır, koyun ve keçilerde BPI3V enfeksiyonunu serolojik olarak araştırarak tür duyarlılıklarına ilişkin olası farklılıklar ile, küçük ru- minantların sığırlar için potansiyel rezervuar rollerinin olup olmadığına dair bilgi edinmek ve ayrıca Afyonkarahisar ili ve çevresinde enfeksiyonun bu türlerdeki varlık ve oranlarını belirlemek amaçlandi.

\section{Materyal ve Metot}

Hayvan Materyali: Bu çalışmada en az bir yıl veya daha uzun süre aynı çiftlikte birlikte yetiştirilen s1ğır, koyun ve keçilerden kan serum örnekleri elde edildi. Afyonkarahisar, Manisa ve Kütahya illerinde bulunan, küçük-orta ölçekli 12 özel çiftlikten 117 s1ğır, 432 koyun ve 302 keçi, toplamda ise 851 örnek elde edildi (tablo 1). Örnekleme sırasında hayvanlar klinik olarak sağl1klı görünümlü idi. İşletmelerde düzenli tutulmuş sağlık kayıtları bulunmamakla birlikte çalışılması hedeflenmiş olan enfeksiyonla ilgili her hangi bir aşı uygulamasının yapılmadığı öğrenildi. Çalışmada doğal enfeksiyona yönelik araştırma yapmak amaçlandığ 1 için, maternal antikor bulunma riskine karşı en az 6 aylık ve üstü bireyler örneklendi. Sığırlar çoğunlukla 1-4, koyun ve keçiler ise 1-3 yaş aralığında idi. Örneklemede cinsiyet açısından bir tercih yapılmamış olmakla birlikte, yaygın yetiştirme tercihleri nedeniyle her üç türde de hayvanların tamamına yakını dişi idi.

Kan örnekleri Vena Jugularis'ten silikonlu vakumlu tüplere alındı ve soğuk zincir altında laboratuara ulaştırıldı. Santrifüj edildikten sonra (3000 devir/dk, $10 \mathrm{dk}$ ) ayrıştırılan kan serumları stok tüplerine aktarıld 1 ve benmaride $56^{\circ} \mathrm{C}^{\prime}$ de $30 \mathrm{dk}$ tutularak inaktive edildikten sonra testlerde kullanılıncaya kadar $-20^{\circ} \mathrm{C}$ ' de saklandilar.

HücreKültürü: Virusun üretilme aşaması, titrasyon ve serum nötralizasyon testlerinde Madin Darby bovine kidney (MDBK) (ATCC, CCL-22) hücre hattı tercih edildi. Vasat olarak da Eagle's Minimal Essential Medium (EMEM) ve testin tipi ile hücrelerin gelişim aşamalarına göre $\% 1$ ile 5 aralığında değişen oranlarda Fötal Dana Serum (FDS) kullanıld1. Hücreler üretildikten sonra testlere başlanmadan once Direkt ELISA ile pestivirus kontaminasyonu açısından kontrol edildiler.

Test Virusu: Çalışmada Ankara Üniversitesi Veteriner Fakültesi Viroloji Anabilim Dalından sağlanmış olan BPI3V'un referens suşu SF-4 kullanıldi. 
Titrasyon: Kontrol virus vasat ile logaritma 10 tabanına göre 8 basamak sulandırıldı ve her sulandırmadan mikropleytin 4 gözüne 100'er $\mu$ l konul$\mathrm{du}$. Virus kontrol için 50'şer $\mu \mathrm{l}$ saf virus ile vasat, hücre kontrol için 100 'er $\mu 1$ serumlu vasat konuldu ve tüm kuyucuklara $50 \mu l$ hücre süspansiyonu (300.000 hücre/ml) ilave edilerek etüve kaldırıldı. Viral üremeye bağlı olarak gelişen sitopatolojiler 24 ve 48. saatlerde incelenerek DKID 50 ve 100 DKID $_{50}$ değerleri hesaplandi.

Serum Nötralizasyon test: $\mathrm{Bu}$ çalışmada BPI3V spesifik antikorlarının tespiti için mikro serum nötralizasyon test (SNT) kullanıldı. Elde edilen kan serumları vasat ile $1 / 5$ oranında sulandırıldıktan sonra 96 gözlü mikropleytin ikişer gözüne $50 \mu$ olarak konuldu. Üzerine eşit miktarda $100 \mathrm{DKID}_{50}$ oranında sulandırılmış referens kontrol virus konularak etüvde $\left(\% 5 \mathrm{CO} 2,37^{\circ} \mathrm{C}\right) 1$ saat inkubasyona birakı1d1. Süre sonunda tüm gözlere aynı miktarda hücre ilave edilerek etüve kaldırıldı. Bir gün sonra doku kültürü mikroskobuyla değerlendirilen örneklerden pozitif olanlar Serum Nötralizasyon ${ }_{50}\left(\mathrm{SN}_{50}\right)$ testine tabi tutuldular. Serum örneklerinin 1/5, 1/10 ..1/160 aralığında seri sulandırmaları aynı yöntemle tekrar test edilerek antikor titre değerleri saptandi.

\section{Bulgular}

Tirasyon Sonuçları: Titrasyon testi sonucunda kontrol virusun doku kültür infektif dozu $\left(100 \mathrm{DKID}_{50} / 0.1 \mathrm{ml}\right) 10^{-4.5}$ olarak tespit edildi.

Serolojik veriler: Serumlarının en az 1/5 oranında yapılan sulandırılmasında viral üreme görülmeyen örnekler pozitif olarak kabul edildi. BPI3V spesifik antikorlar tüm işletmelerde sığır ve koyunlarda tespit edilirken 3 işletmede (2, 4 ve 12 nolu işletmeler) keçilerin tamamının negatif olduğu görüldü. Sığırlarda en düşük oran 9 nolu işletmede $\% 28.5$ (2/7) olarak belirlenirken, 7, 11 ve 12 nolu işletmelerde \%100 seropozitiflik olduğu görüldü, toplamda ise 117 sığırın 90'ının (\%76.9) antikor taşıdı̆̆ 1 tespit edildi. Koyunlarda \%12.5 ile \%43.1 aralığında değişen seropozitiflik, tümünün \%21.9'unda (95/432) saptand1. Keçilerde ise en yüksek oran \%58.3 $(14 / 24)$ ile 6 nolu işletmede saptand1, tüm keçilerin 84'ünün (\%27.8) BPI3V antikoru taşıdıkları belirlendi (tablo 1).

Tablo 1. Örneklenen sığır, koyun ve keçi sayıları ile BPI3V spesifik antikor verileri

\begin{tabular}{|c|c|c|c|c|c|c|c|c|c|c|}
\hline \multirow{2}{*}{ Çiftlik No } & \multirow{2}{*}{ İller } & \multicolumn{3}{|c|}{ Sığır } & \multicolumn{3}{|c|}{ Koyun } & \multicolumn{3}{|c|}{ Keçi } \\
\hline & & HS* & Ab & $\%$ & HS & $\mathbf{A b}$ & $\%$ & HS & $\mathbf{A b}$ & $\%$ \\
\hline 1 & Kütahya & 12 & 6 & 50 & 8 & 1 & 12.5 & 9 & 3 & 33.3 \\
\hline 2 & Kütahya & 17 & 16 & 94.1 & 7 & 1 & 14.2 & 7 & 0 & 0 \\
\hline 3 & Kütahya & 15 & 14 & 93.3 & 6 & 1 & 16.6 & 13 & 4 & 30.7 \\
\hline 4 & Manisa & 9 & 3 & 33.3 & 29 & 6 & 20.6 & 2 & 0 & 0 \\
\hline 5 & Manisa & 9 & 8 & 88.8 & 55 & 7 & 12.7 & 8 & 2 & 25 \\
\hline 6 & Afyon & 4 & 2 & 50 & 27 & 9 & 33.3 & 24 & 14 & 58.3 \\
\hline 7 & Afyon & 11 & 11 & 100 & 71 & 10 & 14 & 57 & 9 & 15.7 \\
\hline 8 & Afyon & 9 & 6 & 66.6 & 56 & 12 & 21.4 & 15 & 3 & 20 \\
\hline 9 & Afyon & 7 & 2 & 28.5 & 80 & 15 & 18.7 & 56 & 13 & 23.2 \\
\hline 10 & Afyon & 4 & 2 & 50 & 58 & 25 & 43.1 & 66 & 13 & 19.6 \\
\hline 11 & Afyon & 10 & 10 & 100 & 25 & 6 & 24 & 40 & 23 & 57.5 \\
\hline 12 & Afyon & 10 & 10 & 100 & 10 & 2 & 20 & 5 & 0 & 0 \\
\hline \multirow{2}{*}{ Toplam } & Gözlenen & 117 & 90 & 76.9 & 432 & 95 & 21.9 & 302 & 84 & 27.8 \\
\hline & Beklenen & 117 & 37 & 31.6 & 432 & 137 & 31.7 & 302 & 95 & 31.6 \\
\hline ATGO** & & & \multicolumn{2}{|c|}{28} & \multicolumn{3}{|c|}{10.9} & & \multicolumn{2}{|c|}{10} \\
\hline
\end{tabular}

HS*; Hayvan Sayıs1 BPI3V Ki-Kare=131.63; $<<0.05$ ATGO $\quad$ **;Antikor titrelerinin Geometrik Ortalamaları

Türlere göre BPI3V antikor titre dağılımları incelendiğinde, sı ğırlarda $1 / 10$ ile $1 / 20$ titrelerde en yüksek seviyenin olduğu ancak $1 / 5$ sulandırmadan itibaren keçilerde titrenin hızla azaldığ 1 , koyunlarda ise keçilere oranla daha 1 lımlı bir azalma gösterdiği belirlendi. 


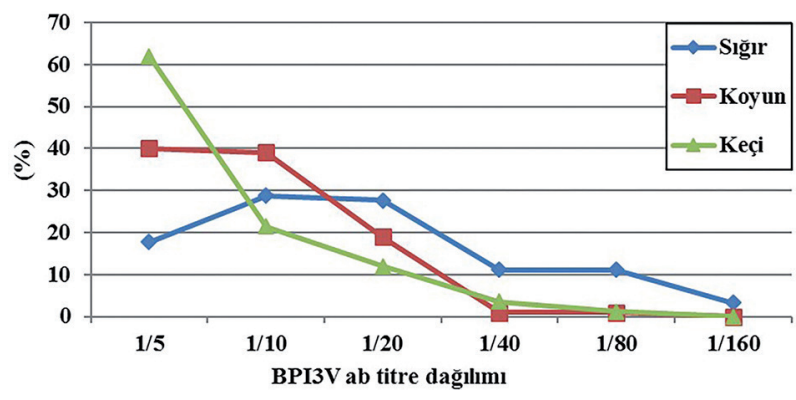

Şekil 1. BPI3V seropozitif sığır, koyun ve keçilerde antikor titre dağılımları

İstatistiksel Analiz: Çalışılan virusa karşı, ki-kare testi kullanilarak yapilan incelemeler sonucunda türler arasında duyarlılık bakımından fark bulunduğu tespit edildi $(\mathrm{p}<0.05)$. Enfeksiyonlara maruz kalma açısından seropozitiflik dağılımları incelendiğinde koyun ve keçilerin her iki enfeksiyona da duyarlılıklarının benzer olduğu ancak sığırların koyun ve keçilere nazaran daha duyarlı olduğu sonucuna ulaşıldı (BPI3V için Ki-kare=131.63; $\mathrm{p}<0.05$ ). Çiftlikler arasında fark bulunmakla birlikte bazı çiftliklerde istatistiksel değerlendirme yapabilmek için yeterli sayıda hayvan bulunmadığı için analizlerde tüm sürülerden elde edilen veriler birlikte değerlendirildi.

\section{Tartışma ve Sonuç}

Her ne kadar koyun ve keçilerin BPI3V enfeksiyonuna duyarlı oldukları biliniyor olsa da, tür duyarl111k farkl11ıklarına dair net bir veri bulunmamaktadır. $\mathrm{Bu}$ araştırmada söz konusu virusun bölgedeki insidenslerinin ortaya konulmasından daha önemli olarak, saha şartlarında yaygın olarak yetiştirilen bu üç ruminant türünde, tür duyarlılık seviyelerine dair veri elde etmek amaçlandı. Örneklerin alınaca$\breve{g} 1$ çiftlikler belirlenirken hayvanların yerli olmaları, söz konusu viruslar için aşısız olmaları, en az son 1 yıl veya daha fazla bir süredir aynı çiftlik şartlarında yetiştirmekte oldukları, çiftlik çalışanlarının değişken olmadığg küçük-orta ölçekli özel çiftlikler olmalarına dikkat edildi. Çalışılan işletmelerin hiç birinde sürü hekimi/danışman bulunmadığ1 ve bakanlık tarafından yürütülen rutin aşılamalar dışında bir aşı uygulaması yapılmadığı kaydedildi. Sahada bu niteliklere haiz, 3 türün birlikte yetiştirildiği çiftliklere oldukça nadir rastlanmaktadır. İşletmelerdeki hayvan sayıları son derece değişken olduğundan ve istatistiksel değerlendirme yapmaya uygun hayvan sayısına her işletmede ulaşılamadığı için çiftlik bazında analizler yapılamadı ve istatistiksel analiz toplam hayvan sayısı üzerinden değerlendirildi.

$\mathrm{Bu}$ çalışmada örnek alınan sürüler yeni oluşturulmuş sürüler değildi ve tümünde toplam sığır sayıs1 30'dan az idi. Sadece birkaç işletmede 100'ün üstünde koyun keçi bulunmakta idi. Sığırlar kış aylarında kapalı ahır şartlarında yetiştirilmekle birlikte hava şartlarının uygun olduğu aylarda küçük ruminantlarla birlikte meraya çıkarılmakta oldukları bilgisi alındı. Koyun ve keçilerin tamamen karışık olarak, sığır barınağı ile bitişik veya çok yakınında yarı açık ağıllarda tutulmakla oldukları, yılın büyük bölümünde meraya çıkarıldıkları ve sulama ünitelerinin çiftlik içinde tüm hayvanlar tarafindan ortak kullanıldığı bildirildi. Ayrıca örnek alınan işletmelerin tamamı aile tipi küçük işletmeler oldukları için, hiç birinde profesyonel çalışan bulunmadığı ve çiftliğin tüm işlerinin aile üyeleri tarafından yapıldığ öğrenildi. Bu şartlar altında virusun direkt-indirekt ve aerosol bulaşma riskinin çok yüksek olabileceği görülmektedir. Ayrıca barınak temizliklerinin genelde tek bir kişi tarafindan yapıldığ 1 ve hayvan sağımının aynı veya farklı ancak yine tek bir kişi tarafından yapıldığı bilgisi göz önüne alındığında, bireyler ve türler arası bulaşmalarda insan faktörünün de önemli olabileceği anlaşılmaktadır.

Elde edilen test sonuçlarına göre, örnek alınan tüm çiftliklerde, tüm sı̆̆ır ve koyunlarda BPI3V spesifik antikorlar tespit edildi. Keçilerde pozitifliğin gözlenmediği 12 işletmenin 3'ünde (2, 4 ve 12 nolu işletmeler) alınan örnek sayısı oldukça az idi (2-7 aras1). Tüm işletmeler değerlendirildiğinde en yüksek oranlar; sığırlarda 3 işletmede \%100, koyunlarda 10 nolu işletmede $\% 43.1$ ve keçilerde ise 6 nolu işletmede \%58.3 olarak belirlendi (tablo 1). Toplamda ise sığırlarda \%76.9, koyunlarda \%21.9 ve keçilerde 27.8 oranları belirlendi. $\mathrm{Bu}$ güne kadar ülkemizin farklı yerlerinde bu üç türde yapılan serolojik incelemeler örneklemenin yapıldığ 1 andan geriye dönük olarak yaklaşık bir yıl içindeki virusa maruz kalma durumunu ortaya koyan saha çalışmalarıdır. Ayrıca örnekleme yapılan işletmelerin genellikle tek bir türün yetiştiriciliğinin yapıldığg işletmeler oldukları dikkat çekmektedir. Araştırmalar BPI3V enfeksiyonunun tüm dünyada olduğu gibi [13, 19, 21, 24], ülkemizin farklı bölgelerinde 
yapılan araştırmalarda sı ğırlarda oldukça yüksek seviyedeki yaygınlığını ortaya koymaktadır. Alkan ve ark. [2] bir çok ilden aldıkları örneklerde \% 52.7 (229/434) oranında BPI3V spesifik antikor varl1ğ1 belirlemişlerdir. Malatya'da \%89.7 (897/1.000) [26], Kuzeybatı Anadolu'da \%43 (251/584) [36], Konya'da \%91.1 (164/180) [15], Aydın'da \%38.2 (110/288) [11], Doğu ve Güneydoğu Anadolu'da \%18 (85/471) [7] oranları bildirilmiştir. Küçük ruminantlarda yürütülen araştırmalar sığırlara göre daha azdır ancak koyunlarda akut solunum sistemi bozukluklarında yüksek seviyede spesifik antikor varlığını bildiren araştırmalar vardır. Yüzbaşıgil [38] 200 adet pnömonili kuzunun akciğer dokusunu incelemiş, 8'inde immuno-histokimyasal yöntemlerle BPI3 antijeni tespit etmiş, bu dokularda yaptığı bakteriyolojik incelemeler sonucunda \%45.50 oranında bakteri izolasyonu yapmış, BPI3V pozitif olan örneklerde örneklerde M. Haemolytica ile P. multocida bakterilerini de izole etmiş, en çok izole edilen etkenin M. haemolytica (\%20.50) olduğunu bildirmiştir. Kuzeybatı Anadolu'da yapılan bir araştırmada toplam 288 koyunda \%8.8 ve 160 keçide \%19.7 seropozitiflik bildirilmiştir [37]. Elazı ̆ ve Malatya illerinde yapılan bir başka çalışmada keçilerde $\% 16$, koyunlarda $\% 7.6$ oranı tespit edilmiştir [20]. Keçilerde yapılan çalışmalarda Turan ve Bolat [32] Diyarbakır ve Şanlıurfa illerinde \%47.1, Van ilinde Ataseven ve ark. [3] \%5.2 (21/407) seropozitiflik bildirmişlerdir. Yener ve ark. [35] Bitlis ve Van illerinde çalışmış, histopatolojik olarak pneumoni teşhisi koydukları keçi akciğer dokularında \%66.6 oranında antijen tespit etmişlerdir. Bu çalışmanın yapıldı̆̆ 1 bölgede, Gür ve ark. [14] Afyonkarahisar, Konya ve Eskişehir illerinden elde ettikleri 1.346 keçi örneğinde \%43.3 seropozitiflik saptamışlardır. $\mathrm{Bu}$ araştırmada keçilerde belirlenen oranlar biraz daha az olmakla birlikte örneklerin bölge, zaman ve sürü farklılıkları göz önünde tutulduğundan normal karş1lanabilir. Tespit edilen oranlar ülkemizde son yıllarda yapılan araştırmalarla karşılaştırıldığında uyumlu kabul edilebilecek değerlerdir.

Virusun epidemiyolojik özellikleri ve işletmelerdeki yetiştirme şartlarına bağlı bulaşma dinamikleri göz önüne alındığında enfeksiyonun tüm türlerde eşzamanlı seyredeceği öngörüldü. Genel olarak, tüm türlerde antikor titreleri yüksek değildi. Her ne kadar grafik 1'de verilen antikor titre dağ1- lımları çiftlik bazında değil, tüm veriler üzerinden hazırlanmış ise de, söz konusu enfeksiyonun örneklemenin yapıldığı zamana çok yakın bir dönemde geçirilmediği anlaşılmaktadır. Yine de yaklaşık son bir yıl içinde klinik veya subklinik olarak doğal enfeksiyona maruz kalındığ 1 ve serokonversiyon şekillendiği görülmektedir. Çalışılan türler içinde BPI3V enfeksiyonuna en duyarlı tür sığırlardır. Koyun ve keçilerin daha az duyarlı oldukları fakat bu iki türde belirlenen oranların birbirine çok yakın olması dolayısıyla duyarlılıklarının da benzer olduğu sonucuna varıldı. Spesifik antikor varlığ 1 üzerinden yapilan istatistik analizlerin ortaya koyduğu bu değerlendirmeyi tam olarak destekleyen bir diğer veri de, seropozitif hayvanlarda belirlenen antikor titre oranlarıdır. Antikor titrelerinin geometrik ortalamaları sığırlarda 1:28 iken, bu değer koyun ve keçilerde sirasıyla $1: 10.9$ ve $1: 10$ olarak belirlendi. $\mathrm{Bu}$ veriler 1şında koyun ve keçilerin, sı ğırlar için rezervuar konakçı rollerinin olamayacağı fakat tam tersinin daha mümkün olabileceği kanısına varıldı. Yine de söz konusu üç türün birlikte yetiştirildiği veya sahada daha sık rastlanan şekli ile koyun ve sığırın birlikte bulundurulduğu işletmelerde, türler arası bulaşmaların her zaman mümkün olduğu göz önünde tutularak, genel yetiştirme şartlarının optimal seviyelerde sağlanmasının yanı sıra, viral enfeksiyonlar ile mücadele çalışmalarında bu türlerin birlikte değerlendirilmeleri gerekmektedir.

\section{Teşekkür}

$\mathrm{Bu}$ çalışma Afyon Kocatepe Üniversitesi Bilimsel Araştırmalar Komisyonu tarafindan 17.KARİYER.117 nolu proje olarak desteklenmiştir. Yazar, çalışmaya istatistiksel analiz konusunda destek veren Doç.Dr.İbrahim KILIÇ’a teşekkür eder.

\section{Kaynaklar}

1. Afshar A, Terlecki S, (1979). Experimental infection of goats with parainfluenza virus type 3 . Zentralbl Veterinarmed B. 26, 641-651.

2. Alkan F, Özkul, A, Karaoğlu MT, Bilge S, Akça Y, Burgu İ, Yesilbağ K, Oğuzoğlu TÇ, (1997). Siğırlarda viral nedenli solunum sistemi enfeksiyonlarının seroepidemiyolojisi. Ankara Univ Vet Fak Derg. 44, 73-80.

3. Ataseven VS, Başaran Z, Yılmaz V, Bilge-Dağalp S, (2010). Van Bölgesi Keçilerinde Parainfluenza Virus-3 (PIV3) ve Bovine Herpesvirus-1 (BHV-1) Enfeksiyonlarinin Seroprevalansı. Y YUniv Vet Fak Derg. 21, 7-9. 
4. Autio T, Pohjanvirta T, Holopainen R, Rikula U, Pentikainen J, Huovilainen A, Rusanen H, Soveri T, Sihvonen L, Pelkonen S, (2007). Etiology of respiratory disease in non-vaccinated, non-medicated calves in rearing herds. Vet Microbiol. 119, 256-265.

5. Bryson DG, McNulty MS, Ball HJ, Neill SD, Connor TJ, Cush PF, (1979). The experimental production of pneumonia in calves by intranasal inoculation of parainfluenza type III virus. Vet Rec. 105, 566-573.

6. Burgu İ, Öztürk F, Akça Y, Toker A, (1984). Karacebey harasi siğırlarında parainfluenza-3 virusunun neden olduğu viral pnömoni olayl. Ankara Univ Vet Fak Derg. 31, 180-185.

7. Çabalar M, Can- Şahna K, (2000). Doğu ve Güneydoğu Anadolu Bölgesinde Süt Siğırlarında Parainfuenza Virus-3, Bovine Herpes Virus-1 ve Respiratory Syncytial Virus Enfeksiyonlarının Seroepidemiyolojisi. Y Y Ü Vet Fak Derg. 11, 101-105.

8. Caldow GL, Edwards S, Peters AR, Nixon P, Ibata G, Sayers $\mathrm{R}$, (1993). Associations between viral infections and respiratory disease in artificially reared calves. Vet Rec. 133, 85-89.

9. Callan RJ, Garry FB, (2002). Biosecurity and bovine respiratory disease. Vet Clin North Am Food Anim Pract. 18, 57-77.

10. Ellis JA, (2009). Update on viral pathogenesis in BRD. Anim Health Res Rev. 10, 149-153.

11. Erol N, Gür S, Yıldırım Y, Tan MT, (2007). Serological Investigation on Parainfluenza-3 (PI-3) and Bovine Adenovirus (BAV) Infections in Dairy Cow Enterprises in Aydın Province. Kafkas Üniv Vet Fak Derg. 13, 43-47.

12. Fulton RW, Purdy CW, Confer AW, Saliki JT, Loan RW, Briggs RE, Burge LJ, (2000). Bovine viral diarrhea viral infections in feeder calves with respiratory disease: interactions with Pasteurella spp., parainfluenza-3 virus, and bovine respiratory syncytial virus. Can J Vet Res. 64, 151159.

13. Gay E, Barnouin J, (2009). A nation-wide epidemiological study of acute bovine respiratory disease in France. Prev Vet Med. 89, 265-271.

14. Gür S, Erol N, Yapıc1 O, (2009). Afyon, Konya ve Eskişehir Illerinde Keçilerde Pestivirus ve Parainfluenzavirus Tip 3 Enfeksiyonlarının Serolojik Olarak Araştırılması. Kocatepe Vet J. 2, 23-27.

15. Gürses E, (2008). Sığırların viral solunum yolu Enfeksiyonlarının Serolojik olarak araştırılması. Yüksek Lisans Tezi, Selçuk Üniversitesi Fen Bilimleri Enstitüsü, Konya.

16. Hartel H, Nikunen S, Neuvonen E, Tanskanen R, Kivela SL, Aho R, Soveri T, Saloniemi H, (2004). Viral and bacterial pathogens in bovine respiratory disease in Finland. Acta Vet Scand. 45, 193-200.

17. Hay KE, Barnes, TS, Morton JM, Gravel JL, Commins MA, Horwood PF, Ambrose RC, Clements ACA, Mahony TJ, (2016). Associations between exposure to viruses and bovine respiratory disease in Australian feedlot cattle. Prev Vet Med. 127, 121-133.
18. Henrickson KJ, (2003). Parainfluenza Viruses. Clin Microbiol Rev. 16, 242-264.

19. Jericho KWF, Darcel Cle Q, Langford EV, (1982). Respiratory Disease in Calves Produced with Aerosols of Parainfluenza-3 Virus and Pasteurella haemolytica. Can J Comp Med. 46, 293-301.

20. Kandil M, Özdarendeli A, Metin N, Gülcü BH, (1996). Elazığ ve Malatya illerinde Koyunlarda ve Keçilerde Parainfluenzavirus Tip-3'e Karşı Hemaglutinasyonu Önleyici Antikorlar Üzerinde Serolojik Araştırma. VHAGProje No: 1038.

21. Lamontagne L, Descoteaux JP, Roy R, (1985). Epizootiological survey of parainfluenza-3, reovirus-3, respiratory syncytial and infectious bovine rhinotracheitis viral antibodies in sheep and goat flocks in Quebec. Can J Comp Med. 49, 424-428.

22. Lehmkuhl HD, Cutlip RC, (1983). Experimental parainfluenza type 3 infection in young lambs: clinical, microbiological, and serological response. Vet Microbiol. 8, $437-$ 442

23. Neill JD, Ridpath JF, Valayudhan BT, (2015). Identification and genome characterization of genotype $B$ and genotype $C$ bovine parainfluenza type 3 viruses isolated in the United States. BMC Vet Res. 11, 112

24. Norstrom M, Skjerve E, Jarp J, (2000). Risk factors for epidemic respiratory disease in Norwegian cattle herds. Prev Vet Med. 44, 87-96.

25. Oem JK, Lee EY, Lee KK, Kim SH, Lee MH, Hyun BH, (2013). Molecular characterization of a Korean bovine parainfluenza virus type 3 isolate. Vet Microbiol. 162, 224227

26. Özdarendeli A, Kandil M, (2001). Malatya'da Siğırlarda Parainfluenzavirus Tip-3 Enfeksiyonu Üzerinde Serolojik Araştırma. Turk J Vet Anim Sci. 25, 223-226.

27. Qiao D, Janke BH, Elankumaran S, (2009). Molecular characterization of glycoprotein genes and phylogenetic analysis of two swine paramyxoviruses isolated from United States. Virus Genes. 39, 53-65.

28. Reisinger RC, Heddleston KL, Manthei CA, (1959). A myxovirus (SF-4) associated with shipping fever of cattle. J Am Vet Med Assoc. 135, 147-152.

29. Richer L, Marois P, Lamontagne L, (1988). Association of bovine viral diarrhea virus with multiple viral infections in bovine respiratory disease outbreaks. Can Vet J. 29, 713717.

30. Şimsek A, Gürçay M, Parmaksiz A, İçen H, Sekin S, Koçhan A, Çelik ÖY, Çakmak F, (2017). Diyarbakır Yöresindeki Siğırların Sindirim ve Solunum Sistemi Problemlerinde Enzootik Bovine Leukosis (EBL), Bovine Viral Diare (BVD), Infeksiyöz Bovine Rhinotracheitis (IBR) ve Mavi Dil (BT) Enfeksiyonlarının Rollerinin Araştırılması. Dicle Üniv Vet Fak Derg. 10, 13-18.

31. Snowder GD, Van Vleck LD, Cundiff LV, Bennett GL, (2006). Bovine respiratory disease in feedlot cattle: Environmental, genetic, and economic factors. J Anim Sci. 84, 1999-2008. 
32. Turan T, Bolat Y, (1999). Diyarbakır ve Şanliurfa yöresinde yetiştirilen keçilerde Parainfluenzavirus tip-3 enfeksiyonunun seroepidemiyolojisi. Fırat Üniv Sağlık Bil Derg. 13, 49-55.

33. Van Der Fels-Klerx HJ, Sorensen JT, Jalvingh AW, Huirne RB, (2001). An economic model to calculate farm-specific losses due to bovine respiratory disease in dairy heifers. Prev Vet Med. 51, 75-94.

34. Yavru S, Şimşek A, Yapkıç O, Kale M, (2005). Serological evaluation of viral infections in bovine respiratory tract. Acta Vet Beograd. 55, 219-226.

35. Yener Z, Sağlam YS, Timurkan N, İlhan F, (2005). Immunohistochemical detection of Parainfluenza Type 3 Virus anti- gens in paraffin sections of pneumonic caprine lungs. J Vet Med. 52, 268-271.

36. Yeşilbağ K, Güngör B, (2007). Seroprevalence of Bovine Respiratory Viruses in North- Western Turkey.Trop Anim Health Prod. 40, 55-60.

37. Yeşilbağ K, Güngör B, (2009). Antibody prevalence against respiratory viruses in sheep and goats in North-Western Turkey. Trop Anim Health Prod. 41, 421-425.

38. Yüzbaşıgil AF, (2010). Kuzu pnömonilerinde patolojik ve Bakteriyolojik incelemeler ile Parainfluenza 3 (PI3) virusunun Etiyolojideki rolü. Doktora tezi, Selçuk Üniversitesi Sağlık Bilimleri Enstitüsü, Konya. 